\title{
COMPETÊNCIAS NAS ORGANIZAÇÕES
}

A discussão sobre competências atrai o olhar e a atenção de especialistas. Tema emergente, é saudado como eficaz mecanismo gerencial, que proporciona ganhos organizacionais ao mesmo tempo em que recompensa o esforço dos indivíduos. Sua relevância passou a ser sentida nas economias ocidentais a partir da década de 1980, com a proposição, nem sempre efetiva, de articulação do sistema produtivo ao sistema educacional. Esse assunto tem suscitado discussões sobre seu significado dentro do mapa teórico da Administração - em particular, da Administração de RH. Sem en- trar no mérito da perspectiva de análise, diversos autores têm se dedicado a elaborar estudos consistentes sobre competências. As indicações abaixo, elaboradas por Allan Claudius Queiroz Barbosa, Professor da UFMG, tentam apontar caminhos recentes que podem ser trilhados na construção de um marco de referências sobre o assunto, sem esquecer autores consagrados, como Richard Boyatizis, que elaboraram suas concepções em períodos anteriores ao demarcado e servem de substrato e constructo científico sobre competências.
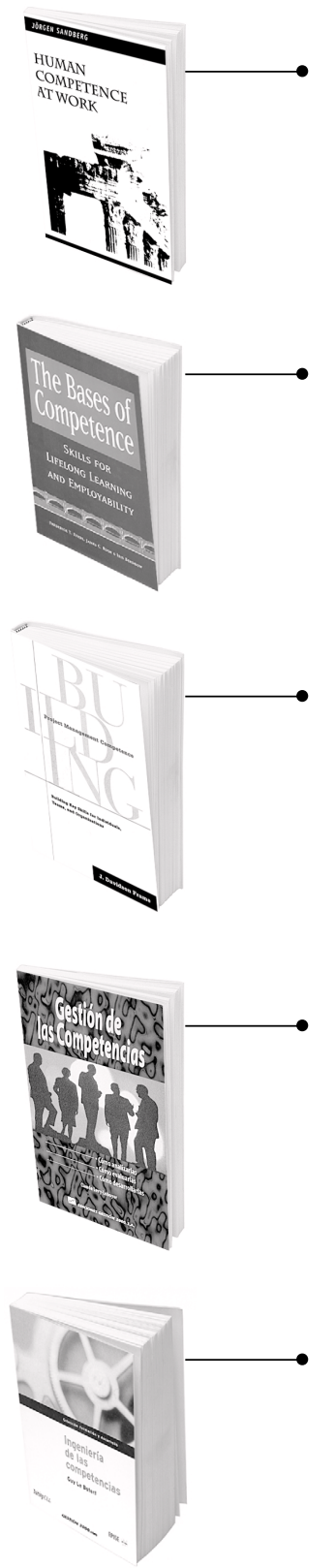

HUMAN COMPETENCE AT WORK: an interpretative approach Jörgen Sandberg. Göteborg : BAS, 1996. 179 p. O trabalho de Sandberg, sueco radicado na Austrália, faz uma contraposição à abordagem racionalista de que o conceito tradicional de competências seria simplesmente um conjunto de conhecimentos, habilidades e atitudes. O autor considera que o desenvolvimento de competências deve ser compreendido com base nas práticas organizacionais por meio de uma abordagem de natureza interpretativa. Ao propor uma "expansão" da idéia de competências, indica a "compreensão do significado do trabalho" como a fase inicial para sua definição.

THE BASES OF COMPETENCE: skills for lifelong learning and employability Frederick T. Evers, James C. Rush and Iris Berdrow. San Francisco : Jossey-Bass, 1998. 273 p.

Os autores discutem nesta obra aspectos relacionados à formação educacional e às bases para a competência, considerando resultados obtidos em um projeto de pesquisa de amplo alcance. A partir da idéia do desenvolvimento de habilidades, reforçam a necessidade de articulação entre educação e trabalho, ao afirmar que educadores e empregadores devem estar alinhados na preparação de estudantes como futuros profissionais que ingressarão no mercado de trabalho.

\section{PROJECT MANAGEMENT COMPETENCE - Building key skills for individuals, teams, and organizations}

J. Davidson Frame. San Francisco : The Jossey-Bass Business \& Management Series, 1999. 272 p.

O autor, que dirigiu o Project Management Institute's (PMI), faz uma discussão com ênfase no gerenciamento de projetos, procurando aproximar o conceito de competências. Ao observar que cada vez mais organizações têm adotado essa perspectiva de gerenciamento e metodologia de operação, sugere uma discussão que identifica três níveis possíveis de competências - individuais, da equipe e da empresa - e, com uma clara preocupação instrumental, indica ferramentas de avaliação e diagnóstico de competências.

\section{GESTIÓN DE LAS COMPETENCIAS - Cómo analizarlas - cómo evaluarlas - cómo desarrollarlas}

Claude Levy-Leboyer. Barcelona : Gestión 2000, 1997. 161 p.

O livro tem sua argumentação construída a partir de cinco questões consideradas centrais. A primeira delas procura discutir o que seriam competências, tendo continuidade em uma reflexão sobre como avaliar as competências individuais, como desenvolvê-las, como integrar informações distintas sobre as competências de forma evolutiva e como relacionar competências individuais e organizacionais. De forma conclusiva, discute o impacto do conceito de competências sobre a gestão de recursos humanos, reiterando seu importante papel nas estratégias organizacionais.

INGENERIA DE LAS COMPETÊNCIAS Guy Le Boterf. Barcelona : Gestión 2000, 2001. 461 p.

A obra, publicada na França e traduzida para o castelhano em 2001, está dividida em duas partes: uma primeira, na qual o autor, reconhecido expert em gerência e desenvolvimento de competências e diretor do Le Boterf Conseil, faz um breve relato teórico situando seis perspectivas que permitem a construção conceitual da chamada ingeneria de las competencias; e uma segunda parte, na qual, como ele mesmo afirma, é apresentada uma espécie de continuidade à obra anterior - De la competénce à la navigation professionelle (1997) -, em que propõe ferramentas e princípios diretivos visando a dar respostas objetivas e operacionais às inquietações organizacionais no âmbito das competências. 